\section{Re: Bekymringsmelding om antibiotika i kyllingfôr}

Tore Midtvedt setter søkelyset på problematikken knyttet til bruk av antibiotika i kyllingfôr (1). Folkehelseinstituttet la 20.05.15 ut en artikkel på nettsiden sin med overskriften «Antibiotikaresistente bakterier funnet hos kylling og mennesker» (2). Der skriver de at mennesker kan bli utsatt for resistente bakterier ved å håndtere eller spise matvarer som inneholder slike bakterier, men at det fortsatt er uklart i hvor stor grad resistente bakterier i kyllingkjøtt kan smitte over til mennesker og gi sykdom. Artikkelen konkluderer med at det er trygt å spise kylling i Norge. En nederlandsk studie har vist en klar sammenheng mellom ESBL-produserende E.coli fra mennesker og kylling (3). Veterinærinstituttet har flere ganger, ved ulike anledninger, opplyst dette (4).

Veterinærinstituttet har også tidligere $\mathrm{i}$ et fagseminar anslått at kilden til de antibiotikaresistente bakteriene i norsk kyllingkjøtt kommer fra importert avlsmateriale (4). Landbruks- og matdepartementet (LMD) har ikke innført forbud mot import av utenlandsk avlsmateriale etter at resistensen ble kjent (5-7). Med tanke på de alvorlige følgende som innføringen av den utenlandske rasen Ross 308 , kan få for den norske befolkningen mener jeg leger, med spesialisering innen feltet, i langt større grad skulle være involvert og ha en avgjørende stemme i avgjørelsene som tas i LMD.

Det har det siste året vært mange oppslag om dagens kyllingproduksjon i media. Den voksne del av befolkningen vet slik sett hva de spiser når de kjøper billig kyllingfilet til middag. Som ernæringsfysiolog tenker jeg på barna som ikke har annet valg enn å spise det de får servert av foreldrene. Barna blir både de mest sårbare og uskyldige i en resistenssituasjon.

Om vi skulle oppleve den alvorlige situasjonen å få E.colibakterier som er resistente mot antibakterielle midler, så er det heller ikke kyllingprodusentene og de ansatte i LMD som blir de lidende, men legestanden. Vakthavende leger som opplever at alt fra små barn til voksne og eldre bringes til sykehusene med alvorlige diagnoser, uten at de som fagfolk kan hjelpe. Stilt ovenfor denne muligheten skulle det være naturlig å være føre var og slutte med den industrielle kyllingproduksjonen, som innebærer importerte rugeegg og antibakterielt stoff i fôret. Løsningen er enkel: Ved å gå over til en norsk kyllingrase som har naturlig vekstkurve, og driftsformer som innebærer dyrevelferd, vil det ikke være behov for å tilsette antibiotika i fôret til kyllingene. Og vi vil få kontroll over hele avlspyramiden og oppdretten.

Jeg er som Midtvedt overrasket over at så mange høyt utdannede folk - både ledelsen på Folkehelseinstituttet, ansatte i Landbruksog matdepartementet, politikere med flere - ikke reagerer på utviklingen som er i ferd med å skje. I en tid der FN oppfordrer til handling for å øke ansvarligheten og stanse spredningen av resistens, ser det ut til at myndighetene i Norge setter næringsinteresser foran befolkningens helse.

\section{Elisabeth Gard}

post@butterfly-season.no

Elisabeth Gard (f. 1959) er ernæringsfysiolog med mellomfag i medisin. Ingen oppgitte interessekonflikter.

\section{Litteratur}

1. Midtvedt T. Bekymringsmelding om antibiotika i kyllingfôr. Tidsskr Nor Legeforen 2015; 135: 742

2. Folkehelseinstituttet. Antibiotikaresistente bakterier funnet hos kylling og mennesker. www.fhi.no/eway/default.aspx?pid=239\&trg=Content_6496\&Main $6157=6263: 0: 25,5785 \&$ MainContent $6263=6496: 0: 25,5793 \&$ Content $6496=6178$ : 115059:25,5793:0:6562:1:0:0 (25.5.2015)

3. Overdevest I, Willemsen I, Rijnsburger M et al. Extended-Spectrum ?-Lactamase Genes of Escherichia coli in Chicken Meat and Humans, the Netherlands. Emerging Infectious diseasses 2011, vol 17 www.nc.cdc.gov/eid/article/17/7/ 11-0209 article (25.5.2015).

4. www.vetinst.no/Nyheter/Hvordan-bekjemper-vi-resistente-E.coli-i-norskkylling/(language)/nor-NO (25.5.2015)

5. NORM/NORM-VET. 2007. NORM/NORM-VET 2006. Usage of Antimicrobial Agents and Occurrence of Antimicrobial Resistance in Norway (Tromsø/Oslo).

www.sciencedirect.com/science/article/pii/S0378113514000765 (27.5.2015).

7. www.nortura.no/nyhetsarkiv-2013/nortura-med-omfattende-esbl-tiltakspakkearticle35484-17521.html (25.5.2015).

\section{T. Midtvedt svarer:}

Jeg takker for ernæringsfysiolog Gards veldokumenterte og velformulerte støtte til min bekymringsmelding. Det varmer når man får støtte i en sak hvor man offentlig har gått i mot både politiske og faglige myndigheter. Jeg deler fullt ut hennes forbauselse over at «så mange høyt utdannende folk - både ledelsen på Folkehelseinstituttet, ansatte i Landbruks- og matdepartementet, politikere med flere» velger taushet framfor handling. Selvfølgelig vet vi at disse myndighetene har nedsatt flere komiteer for å vurdere noe som egentlig er forbudt ved norsk lov, nemlig antibiotika som tilsats til dyrefor. Konklusjonene synes gitte, kunne vi begge bare avvente løsningene.

Problemet er bare at i mellomtiden vokser problemene med spredning av multiresistente bakterier både i miljø og befolkning, og dermed også økt infeksjonsfare. Jeg deler Gards bekymring om at dette i særlig grad vil ramme både de mest sårbare og uskyldige i samfunnet og legestanden. Men uansett hvem som rammes er problemet for alvorlig til at løsningen kan overlates til fremtiden. Skal problemet løses raskt, tror jeg at det er helt nødvendig med en fortsatt massemedial oppmerksomhet, slik at salg av infiserte kyllingprodukter fortsetter å minske. Det vil raskere enn noen komiteutredning kunne føre til endringer i norsk broilerproduksjon slik som skissert $i$ innlegget til Gard. Jeg er overbevist om at Mattilsynet vil følge nøye med i denne overgangsperioden, slik at ikke infiserte kyllingprodukter blir blandet inn i andre kjøttvarer.

Egentlig tror jeg at både produsenter og vi forbrukere har en felles målsetting: Norske kyllingprodukter skal være av høy kvalitet og ikke inneholde hverken antibiotika eller multiresistente bakterier. Det kalles mattrygghet. Kylling er faktisk talt godt.

\section{Tore Midtvedt}

toremidtvedt@ki.se

Tore Midtvedt (f. 1934) er spesialist i medisinsk mikrobiologi og professor emeritus ved Karolinska Institutet i Stockholm.

Ingen oppgitte interessekonflikter.

\section{Re: Kreasjonismen er aldri morsom}

I Tidsskriftet nr. 1/2015 anmeldte høgskolelektor Erik Tunstad boken «Intelligently Designed» (1). Jeg har fått flere henvendelser fra kolleger som har reagert på denne anmeldelsen. Tunstad skriver nedlatende om «kreasjonisme», og det må han gjerne gjøre. Kreasjonisme betyr skapelse - det vil si man innfører en Skaper. Man bør vite at det er to slag slik kreasjonisme: Ung jord kreasjonisme, hvor man mener at jorda ikke er over 10.000 år gammel, og gammel jord kreasjonisme, som har det vanlige syn på universets og jordas alder, det vil si noen milliarder år (2). I dag er det slik at «kreasjonisme» i realiteten betyr tilhengere av ung jord.

Tunstad skriver at Intelligent Design (ID) er en form for kreasjonisme. Det mener jeg er fullstendig feil. ID er en vitenskapelig retning som stiller spørsmålet: Er det forhold i vår virkelighet som naturalistiske mekanismer ikke kan forklare, og som best forklares med intelligent aktivitet? Dette spørsmålet er ikke knyttet til jordas alder, og ID innfører heller ikke et gudsbegrep. Jeg mener derfor det er uriktig å knytte ID til «det kristenkonservative USA i kamp mot modernismen». Naturalismen, som er det rådende syn på naturvitenskap, regner ikke med og aksepterer ikke på noen måte, intelligente årsaker i naturen. Der er det bare naturlige årsaker, det vil si tilfeldighet og lovmessighet, som gjelder.

ID stiller spørsmål ved om følgende forhold kan gis en akseptabel forklaring hvis intelligent kausalitet utelukkes:

1. «The fine-tuning of the universe». Selv naturalister forstår at denne fininnstilling av en stor rekke med naturkonstanter, et forhold som utgjør en betingelse for at vårt univers i det hele kan være til, sterkt indikerer intelligent kausalitet. Derfor blir dette argument imøtegått ved å innføre tallrike univers, multivers. 